\title{
Journalism and the Black Short Story in English in Twentieth-Century South Africa: From R. R. R. Dhlomo to Miriam Tlali
}

\begin{abstract}
:
In the present article I seek to discuss, following a diachronic approach, the close-knit relationship that can be found between journalistic discourse and the genre of the short story in Anglophone South African literature over a time span of fifty years, between the late Twenties and the Eighties. In particular, I intend to explore this genre negotiation by close reading selected short stories and/or newspaper articles by four nonwhite South African writers: R. R. R. Dhlomo, Can Themba, Alex La Guma, and Miriam Tlali. The intersections between the two different genres and discourses in these hybrid texts can be identified at the level of both content and form. A close reading of selected short stories and/or articles may call for a revaluation of this "South African New Journalism" as a creative experimentation that challenges conventional generic categorisations.
\end{abstract}

Keywords:

South Africa, short story, literary journalism, New Journalism, genre contamination

Sintesi:

Nel presente articolo si intende discutere la profonda interdipendenza che sussiste tra il discorso giornalistico e il genere letterario del racconto breve nell'ambito della letteratura sudafricana in lingua inglese tra la fine degli anni Venti e gli anni Ottanta, seguendo perciò un approccio diacronico. In particolare, il presente articolo si propone di esplorare questa contaminazione partendo dall'analisi testuale di una selezione di racconti brevi e/o articoli giornalistici scritti da quattro autori afro-discendenti: R. R. R. Dhlomo, Can Themba, Alex La Guma, e Miriam Tlali. L'intersezione tra i due diversi discorsi e generi testuali può essere individuata sia a livello formale che contenutistico. Il close reading dei racconti brevi e/o degli articoli selezionati può contribuire a una rivalutazione di questo caso di "New Journalism sudafricano" in quanto sperimentazione formale che mette in discussione categorizzazioni convenzionali a livello di genere testuale. 
Parole chiave:

Sudafrica, racconto breve, giornalismo letterario, New Journalism, contaminazione

The development of works of non-fiction was famouslygiven newimpetus, and increasingly acquired prestige worldwide as "literature", under the now-renowned movement of New Journalism, which developed in the Sixties in the United States. ${ }^{1}$ US journalists and writers of the calibre of Truman Capote, Tom Wolfe, Joan Didion, and Norman Mailer were among its most celebrated proponents. The pieces of New Journalism have been variously defined as "works of fictionalised social history", "literature of fact", "forms of narrative reportage" (Hollowell 1977: 10). These definitions all point to the experimental and hybrid nature of the journalistic works produced by the authors of New Journalism, who adopt techniques that are usually typical of fictional texts, thus revolutionising the objective style of traditional journalism (Worthington 2018: 92). As a consequence of New Journalism, the cultural prestige traditionally associated with fictional texts - "literature" in its strictest sense - began to be reclaimed by this hybrid form of non-fiction, to the point that works of literary journalism are now awarded prestigious international prizes usually reserved to "literature" such as the Nobel or the Windham-Campbell Prize. ${ }^{2}$

While the texts written by the exponents of New Journalism tend to be rather long narrative reportages, thus promoting a hybrid genre that became known as the "nonfiction novel" (Worthington 2018: 93), I would like to focus my discussion on the short-story genre's relationship with journalism instead. Several critical studies have stressed the generic permeability of short stories, and in particular their closeness to factual and journalistic discourse. Valerie Shaw, in her seminal study on the short-story form, states that the genre has the "marked ability" of bringing the two stylistic extremes of the journalistic and of the poetic together (Shaw 1983: 6; see also Pratt 1994: 103). More recently, Farhat Iftekharrudin's edited monograph on the forms of the postmodern short story, The Postmodern Short Story: Forms and Issues (2003), devotes a whole section to the intersecting trajectories of fiction and non-fiction in selected short narratives (see, in particular, Morano 2003; Orlofsky 2003). Interestingly enough, both Iftekharrudin (2003: 23) and Worthington (2018: 106) identify in the postmodernist theorisation of the blurring of lines between the real and the invented, fact and fiction, the main explanation for the development and proliferation of hybrid short stories on the one hand, and of the non-fiction novel of New Journalism on the other.

The debate around the opposition and intertwining of fiction and non-fiction, literature and documentary forms, has been pervasive also in South Africa due to the country's peculiar socio-political situation, which has divided its population along racial lines. Compared to the more influential and famous transatlantic experimentation of New Journalism, the South African works of literary non-fiction are thus mainly motivated by the pervasive presence of 
politics in every aspect of South African life, or, as Twidle has it (2012: 6), by the "reality hunger" in the South African literary panorama, rather than by postmodernist theories. In particular, the discussion on the role of instrumental literature in documenting the country's segregated society and struggle to achieve democracy has found fertile ground in South Africa (see, among others, Sachs 1998; Bethlehem 2001). ${ }^{3}$ In turn, works of literary non-fiction abound and have become particularly prominent in the post-Apartheid era, as Hedley Twidle observes (2012: 8).4 To name an example, the masterpiece of Antjie Krog, Country of My Skull, probably South Africa's best-known work of literary non-fiction, was published in 1998. ${ }^{5}$ Twidle's own essay is inserted in a Safundi issue of 2012 especially devoted to the discussion of the opposing - but intersecting - concepts of literature/history and fiction/non-fiction in contemporary South Africa. Yet, interesting hybrid instances of journalistic texts displaying fictional features, or, on the contrary, literary texts with a curtailed fictionality, do characterise also the black literary history of South Africa in its pre-Apartheid and Apartheid years: "[j]ournalism and literature are, for a long time in South African black literary history, Siamese twins" (Couzens 1976: 20). 6 The hybrid texts written before 1994 - for the most part by black writers - can be considered antecedents to the theorisation of New Journalism and to the kind of work produced in the post-Apartheid period. The main locus for the intersection of the journalistic and the literary in South African English culture before 1994 is tellingly represented by the genre of the short story. ${ }^{7}$

In light of these considerations, in the present article I seek to discuss, following a diachronic approach, the close-knit relationship that can be found between journalistic discourse and the genre of the short story in Anglophone South African literature over a time span of fifty years, between the late Twenties and the Eighties. In particular, I intend to explore this genre negotiation by close reading selected short stories and/or newspaper articles by four non-white South African writers: R. R. R. Dhlomo, Can Themba, Alex La Guma, and Miriam Tlali. The intersections between the two different genres and discourses in these texts can be identified at the level of both content and form. Before analysing the selected corpus in detail, I would like to discuss briefly the role of the English-language black press in pre-Apartheid and Apartheid South Africa and to investigate the substantial proliferation of short stories by black writers in the same period, two interrelated phenomena.

The Bantu World, the first national African newspaper, was founded in 1932 by R. V. SelopeThema. The diffusion of the black press was instrumental in promoting the socio-political and cultural development of South Africa - indeed, the rate of literacy among Africans increased significantly in the Thirties (Peterson 2006: 239). The Bantu World, and the black South African press more generally, adopted a double strategy acting as "a catalyst" in fostering new reading habits on the one hand, and becoming the "forum" for the publication of writings, both journalistic and literary, by black intellectuals on the other hand. Consequently, the black press represented "one of the most important sites for the first sustained publication of literary endeavours" by African writers (idem: 251). Indeed, the only outlets for publication available to them in the first half of the twentieth century were either the mission presses or newspapers 
Cadernos de Literatura Comparada

Journalism and the Black Short Story in English in Twentieth-Century South Africa

and magazines edited by the black intelligentsia - not surprisingly, the writer-journalist was a common figure among African intellectuals (Visser 1976: 43). ${ }^{8}$

Literature promoted by journalistic publications consisted mainly of poetry and, more importantly, short stories, which, as we have already seen, are particularly open to contamination by other genres and discourses. First and foremost, the short-story form was favoured for obvious reasons of space: compared to the novel, it could be easily published in the newspapers' format without the need for serialisation. Moreover, the material conditions of production and circulation of short fiction in newspapers proved to be particularly apt for writers and readers living under an oppressive regime like South Africa's, allowing for a rapid production and circulation of literary knowledge (Wicomb 2001: 164). Perhaps more importantly, the newspapers' preoccupation with social critique and public pronouncement, and their documentary impulse - the ethics of writing - are often reflected in both the style and theme of the short stories published in newspapers and magazines (see Couzens 1974: 5). The result is a cross-pollination between the discourses of journalism and short fiction, a cross-pollination that characterises South African literary culture between the late 1920 s and the 1980 s.

Rolfes Robert Reginald Dhlomo (1901-1971), a prolific journalist and writer, is best known for being the first black South African to publish a novel in English, An African Tragedy, in 1928. However, he also wrote a series of short stories in English between 1929 and 1933, which appeared in two different newspapers to which he contributed regularly: the whiteowned weekly Sjambok, addressing a white readership, and The Bantu World, edited by black intellectuals and targeting educated, middle-class African readers. ${ }^{9}$ Since they have never been published in book form, Dhlomo's short stories were discovered only late by Tim Couzens, who edited a special issue of English in Africa in 1975, "Twenty Short Stories by R. R. R. Dhlomo", with a selection of the author's short prose fiction. Dhlomo's texts are "certainly among the earliest - if indeed they are not the earliest - short stories written in English by a black South African", as Couzens himself remarks in the preface to the author's narratives (1975a: 1).

Couzens' edition of Dhlomo's work, however, also includes six hybrid articles/short stories - a very interesting case of generic indeterminacy. It is worth quoting Couzens' preface to these pieces:

They are included because they give a good idea of how some of the stories originate, and they show that the early black South African writer was less concerned about literary sensibility and more preoccupied with concrete issues springing directly from his immediate environment. (Couzens 1975b: 52)

Indeed, the connections between some of Dhlomo's stories and articles are noteworthy. As R. R. R. Dhlomo's younger brother Herbert remarks about his sibling, "[r]eportage, feature articles, etc. became grist for his literary mill" (Dhlomo 1975: 10). The article "Wholesale Dog Murder" is exemplary in this regard, and it is textual evidence that Couzens' comment on the 
origin of Dhlomo's short stories is critically to the point. The article was published on $6^{\text {th }}$ June 1930 in the Sjambok, and it recounts the cruel slaughter of stray dogs in a mine compound on the part of 150 indunas..$^{10}$ Six weeks after the publication of "Wholesale Dog Murder", a short story by the title "The Dog Killers" appeared in the Sjambok, prefaced by the editor with a sort of declaration of authenticity: "This native story is of great interest because it is based on a recent episode in Johannesburg with which the writer was acquainted" (see Dhlomo 1975c: 26). The story is written in a realistic style, and it differs from the article only because it is focused on a single character (Zander 1999: 246). Thus, the direct causal connections between a real event, its representation in the news and its representation in fiction becomes transparent in the work by Dhlomo, who even uses the same expressions in the two texts. ${ }^{11}$

Perhaps more interesting from a stylistic point of view is the article "The Compound Induna and Compound Interest". Also from 1930, it denounces a scene of corruption inside a mine compound perpetrated by indunas. The short factual introduction of the article is written in a journalistic mode (Zander 1999: 247), but it is followed by the expression "NOW READ" and by two pages of continuous dialogue between Breakfast and Sixpence, two mine workers discussing the role of indunas in the compound and their exercise of bribery and robbery. The role of the journalist (or maybe we should say narrator) is here confined to some brief indications, signalled by parentheses, such as "(Smacks his lips)" (Dhlomo 1975a: 64), which almost resemble stage directions. It seems that the journalist Dhlomo chose to let the dialogue speak for him. The insertion of dialogue is usually assumed to be a fictional device; in his volume on New Journalism, Hollowell lists six fictional techniques used by New Journalists in their pieces, and among them he also includes "recording dialogue fully rather than with the occasional quotations or anecdotes of conventional journalism" (Hollowell 1977: 25). Dhlomo's tendency to fictionalise in this "article", however, is not limited to the mere insertion of dialogue: readers are given no hints whatsoever regarding the veracity of the dialogue. There is no indication of time nor of place, and the two protagonists resemble exemplary characters rather than real-life figures. Because of these features, this text falls into the category of literary journalism. ${ }^{12}$

Instances of genre contamination are to be found not only in the articles that Dhlomo published in the Sjambok, but also in some of those texts that Couzens classifies as short stories, and particularly Dhlomo's short fiction on traditional African customs that appeared in The Bantu World, such as "Ukugweba". Published in 1932, it describes a rite performed by witchdoctors on children in traditional African societies and it displays interesting paratextual elements. Its subtitle recites "Cruel Custom of 'Ukugweba' Still Widely Practised Among the Bantu", which immediately reminds readers of a journalistic subtitle (see also Zander 1999: 409). To enhance the factuality of the text, a preface by the editor precedes the story - a common device, as we have already seen:

In a covering letter to the Editor, Mr Dhlomo, who is known to readers of The Bantu World as an interesting writer on Bantu Customs, states that just a few months ago he actually saw a 
Cadernos de Literatura Comparada

Journalism and the Black Short Story in English in Twentieth-Century South Africa

Christian married couple putting their nine-months-old child through the rite of "Ukugweba". The grim story dealing with this custom which the writer starts in articles printed below, will be concluded in next week's issue. (see Dhlomo 1975d: 39; my emphasis)

This preface stresses the documentary value of the recounted episode. The use of both the words "story" and "articles" is textual evidence of the ambiguity regarding the generic classification of "Ukugweba"; the short story, moreover, is printed in The Bantu World's section entitled "News and Special Feature Articles". Dhlomo begins his narration with a maxim "Superstitious beliefs die hard" (1975d: 40) - and he then explains to readers what the rite of ukugweba is and why it should be abolished. After this rather factual explanation, the "I" of the narrator/journalist appears in the text: "To prove this claim, I will quote the actual words of a modern witchdoctor which will also serve to pave the way for the grim story I am about to relate" (idem: 40); the quotation from the witchdoctor follows, with the details of the time and place of his utterance. After this introductory section, the "grim story" begins, and the first-person narrator disappears to give way to a third-person omniscient narrative voice. The narrative structure of "Ukugweba", therefore, together with the context of publication, poses interesting challenges to the sensibility of twenty-first-century Western readers as to what can be defined as a fictional short story. ${ }^{13}$

The short fiction by R. R. R. Dhlomo, therefore, moves in two different directions. On the one hand, his articles written for the white readership of the Sjambok, such as "Wholesale Dog Murder" and "The Compound Induna and the Compound Interest", document and denounce the coeval situation in the mine compounds of Johannesburg, where Dhlomo himself had worked as a clerk and where black workers were exploited by both their white chiefs and black overseers (Gaylard 2008: 42). The dramatization of events - the use of dialogue, the transposition of a real-life situation into the realm of fiction - allows Dhlomo to secure an audience (see Hollowell 1977: 14). On the other hand, the pieces he wrote for The Bantu World on traditional customs, categorised by Couzens as short stories, are often characterized by the interventions of a first-person narrator who stresses the authenticity of his account and who provides readers with factual explanations and hints at how to interpret the story. This narrative voice seems to endorse Dhlomo-the-journalist's own views on society, and the boundary between moral short story/article to educate readers thus becomes blurred:

The way Dhlomo switched from a factual to a fictional treatment of the same topic indicates once more that the author regarded fictional discourse merely as another and more effective way of conveying information on his subject, not, however, as a separate mode aimed at altogether different goals. [...]. Not surprisingly, in this series he presented texts which do not reveal whether they are fictional or factual but tend to abolish such a distinction and hence appear rather as "factional" pieces. (Zander 1999: 129) 
As far as R. R. R. Dhlomo is concerned, therefore, the cross-pollination between journalism and the short story derives from several interrelated factors: the ethical imperative of documenting a certain social situation; ${ }^{14}$ the role of the journalist as society's "moral guide", educating readers towards his views; ${ }^{15}$ the coeval publishing conditions in South Africa and, ultimately, the function and format of newspapers themselves. This results in a precise thematic correspondence between articles and short stories, in the use of fictional devices in Dhlomo's articles, and in rather brief, sketchy, and didactic stories with factual introductions and an authoritative first-person narrative voice. As Nick Visser remarks, both R. R. R. Dhlomo and, though with some differences, his brother Herbert, ${ }^{16}$ "mark the transition from the early writers, who established the characteristic type of the black South African writer, the journalist-author, and set the precedent, to the generation which emerged in the fifties, for working in factual narrative modes" (Visser 1976: 46).

The generation of writers-journalists that came to the fore in the Fifties and to which Visser is referring is commonly known as the Drum generation - the writers orbiting the popular magazine Drum, founded in 1951. Together with love dramas and popular columns on jazz, sports, American movies, and detective stories, the magazine also published serious investigative journalism and fiction by authors who were later to enter the South African canon or who had already established their fame (see Cowling 2016). More importantly, the periodical started launching successful short-story competitions, inaugurating a practice that was to be imitated by other South African magazines. Because of its success, both in South Africa and abroad, and because of its eclecticism, Drum is perhaps the most known and studied magazine of South Africa's literary history, often shadowing the pioneering significance of its precursors, such as The Bantu World (see Sandwith 2018: 17). Several critical studies underline the seamless integration of Drum's short stories and articles, often resorting to the term "literary journalism" (see Choonoo 1997; Cowling 2016). The fictional devices used by the Drum writers in their articles include scene-by-scene description, either first-person perspective or internal focalization, and the use of local lingo (Cowling 2016: 11). ${ }^{17}$

As Walter Ehmeir suggests, however, there were three different kinds of periodicals publishing literature in South Africa in the Fifties: literary magazines, ${ }^{18}$ left-wing political periodicals, and newspapers with a mass audience such as Drum (Ehmeir 1995: 114). Indeed, even though the second half of the twentieth century in South Africa was marked by the institutionalisation of Apartheid in 1948, the segregative legislation did not stop the eruption of literary activity in the following years, as testified by the boom of new little magazines and newspapers, some of them politically inflected: New Age, Fighting Talk, Africa South, The Purple Renoster, and The Classic, to name a few (see Ehmeir 1995). All of them published short stories and became the principal site for the intertwining of ethics and aesthetics investigated in this article. The publishing panorama in South Africa in the Fifties, therefore, was extremely heterogeneous and complex. Popular magazines such as Drum also featured investigative journalism and short stories (or a mixture of both), political periodicals such as New Age and Fighting Talk also published short fiction, and literary magazines were open to the category of 
Cadernos de Literatura Comparada

Journalism and the Black Short Story in English in Twentieth-Century South Africa

the political, particularly pregnant in South Africa's divided society. At the same time, each of these publishing venues promoted its own literary standard, which often clashed with the established, mainly Western, idea of literariness (McDonald 1980: 118-119). The writing of short stories in this decade, therefore, depended on these conflicting trajectories.

The boom of literary journalism, or narrative reportage, of the considered period and its closeness with the short-story genre is also testified by some of the posthumous anthologies that gather the works of the Drum generation. Several of these anthologies, indeed, collect both short stories and journal articles in the same volume, as if the two discourses were inseparable. The anthologies on the works of Drum writer Can Themba (1925-1967) are exemplary in this regard. The Will to Die (1972), the first anthology on Themba, is divided into "stories", "reports", and miscellaneous prose writing; the 1985 anthology edited by Essop Patel, The World of Can Themba, offers a somewhat wider selection of the writer's works, but the volume is similarly divided into short stories, journalism, and remembrances. Interestingly, some of the pieces are categorised differently in the two anthologies. Themba's more mature short stories all deal with socio-political themes and are characterised by precise stylistic traits, apart from their realism: the use of the present tense and of a homodiegetic narrator, often resembling the author, and the recourse to mimetic speech in dialogues. These features make it more difficult for readers and scholars alike to distinguish the writer's reports for Drum from his socially committed short fiction. It is in this group of stories that the engaging intersection between fiction, autobiography, and journalism - ethics and aesthetics - becomes more visible in Themba's work. ${ }^{19}$

The mixture of journalism and fiction is transparent in "The Dube Train", a fictional story closely associated with an article Themba wrote for Drum in 1957, "Terror in the Trains". Indeed, in November 1957 Themba investigated the inter-ethnic violence in the Dube area near Soweto, Johannesburg, which resulted in a Drum report, "Terror in the Trains" (see, among others, Gaylard 2008: 109-111). Before turning to a close reading of "The Dube Train", it may be interesting to mention a few things on its (literary-) journalistic counterpart, "Terror in the Trains". First of all, its publication history is telling of the hybrid nature of the piece: Donald Stuart and Roy Holland, the editors of The Will to Die, chose to print the article cutting the first paragraph and the last few sentences (see Themba 1982: 68-71), as a comparison to the unabridged version of "Terror in the Trains", published in The World of Can Themba, can show.

The first paragraph of the article describes a man, readers do not know if real or invented, coming home from work by train:

Friday night, and the end of the month to boot. That's why, joining the hordes that flowed into Park Station, Johannesburg, Isaac Moeketsi of Dube - and thousands like him - was scared. He had, to a more intense degree, that sinking, uneasy feeling he always got when he had to board any of these location trains. More intense because he knew that robbers would be making an extra-effort on this most special of nights. (Themba 1985: 111) 
The opening of "Terror in the Trains" is thus marked by the presence of an external narrator who describes someone's thoughts in the past tense - readers probably assume that Isaac Moeketsi is a fictional character. After this "fictional individualized characterization" (Zander 1999: 232), Isaac disappears and Themba-the-journalist shifts to the present tense and to the first person to depict the dangerousness of trains in the Dube area in general terms. Possibly, the editors of The Will to Die wanted "Terror in the Trains" to fit neatly into the anthology's section "Reports", and this is why they cut the "literary" part of the piece without any indication of the abridgement (see Zander 1999: 232). The article, moreover, often shifts in narrative perspective, and the initial heterodiegetic narrative voice alternates with the use of the plural first-person pronoun and the immediacy of the eye-witness account (Cowling 2016: 23-24). The use of the first-person perspective and the direct involvement of the journalist in the exposés he writes, a typical feature of Drum articles, allow for the emergence of yet another parallelism with New Journalism:

self- styled 'New Journalists' turned away from the traditional role of the objective outsider recording observations. Rather, they became famous for throwing themselves headlong into their stories by immersing themselves in the world they were investigating. [...] Often (but not always) the complete submersion of the writer into his/her subject matter resulted in the inclusion of the writer's own persona within the resulting narrative. Some of these New Journalists began routinely breaking one of the cardinal rules of journalism by depicting themselves as integral parts of the story. (Worthington 2018: 93)

The narrative structure of a first-person eye-witness account characterizes also "The Dube Train", the story of an anonymous worker's journey by train from Dube Station. As in "Terror in the Trains", precise indications of the day of the week and of the route of the train are given: "The Orlando train comes from the right. It crosses the Dube train overhead just before we reach New Canada" (Themba 1985: 36). ${ }^{20}$ Unlike "Terror in the Trains", however, the short story recounts a single episode involving a young township criminal who boards the same train as the narrator, a device that contributes to achieve the unity of effect first theorised by Poe for the short story (Gaylard 2008: 111).21 Thus, while on the one hand the fictional story presents some traits that are closer to reportage - the structure of the eye-witness account and the precise outlining of time and setting - on the other hand the literary features of the article "Terror in the Trains" are so prominent that they needed abridgement to fit the category of "reports" in Themba's 1972 anthology.

The proximity of the spheres of literature and journalism, of aesthetics and ethics, becomes even more prominent in the work by Alex La Guma (1925-1985), a Cape Town-based journalist and writer deeply active in politics and in the liberation struggle against Apartheid. La Guma's early engagement with politics in the Fifties coincides with his first published journal articles, and with his first short stories a few years later (Field 2010: 48-69). As Field suggests (idem: 97), there is a "fluid" and "dynamic" relationship between La Guma's 
Cadernos de Literatura Comparada

Journalism and the Black Short Story in English in Twentieth-Century South Africa

journalism and short fiction in the second half of the Fifties, when he contributed regularly to, among others, New Age, Fighting Talk - both political periodicals - and, more sporadically, Drum. ${ }^{22}$ Interestingly, Andre Odendaal and Roger Field, the editors of a posthumous collection of New Age and Fighting Talk newspaper articles by the writer, titled Liberation Chabalala: The World of Alex La Guma (1993), include two short stories in their editorial selection, "Out of the Darkness" and "A Matter of Honour", because of the "several connections worth pursuing": the main thematic concerns of the short stories by La Guma are often first expressed in his early newspaper articles (Odendaal/Field 1993: xvii).

The narrative "Out of Darkness", originally published as "Out of the Darkness" in 1957 in Ronald Segal's Africa South, is notable for its indirect critique of the prison system in South Africa, a problem which had also been addressed by Drum in $1954 .{ }^{23}$ Through the device of the story in the story, a first-person narrator reports an anecdote that one of his prison inmates tells him. At the same time, the narrative voice describes the harsh treatment he received from other prisoners and guards alike. In the months of September and October 1956, a year before the publication of "Out of Darkness", La Guma contributed three articles to New Age, one on the juvenile condition in District Six, Cape Town, and the other two on the Cape Town prison in Roeland Street. ${ }^{24}$ All three articles contain the deterministic idea of the jail as a "jungle"; the same concept is repeated in the short story "Out of Darkness", together with a series of verbatim reproductions of expressions used in the three articles (Zander 1999: 259). The use of the same imagery and expressions is textual evidence of a direct connection between journalism and short-story writing, intersecting at the crossroads of politics, in La Guma's work.

The documentary import of "Out of Darkness" and of the late short fiction by Themba represent a common trend of the short stories of the period. For instance, the preface to the winning entry of the 1956 New Age short-story competition refers to the narrative "The Family Boy" by Fezile Mbi as a "deeply moving human document" that describes township life in a way that "will ring true" to its readers (see Mbi 1956: 6). A preface of this kind, with an emphasis on the authenticity of the presented fiction as if it were a document of social diagnosis, is reminiscent of the editor's note introducing the prose fiction by Rolfes Dhlomo in The Bantu World and the Sjambok in the early Thirties.

If "Out of Darkness", though originating from articles, is clearly a fictional short story, the article "Ten Days in Roeland Street Jail" falls into the category of literary journalism: with the aid of literary techniques - see the alliteration "blue bulk of Table Mountain in the background" at the beginning (La Guma 1993b: 14; my emphasis) - it narrates the experience in jail of a certain Willie Frazer with frequent shifts between the present and the past tense, and between reported speech and the narrator's descriptions (Odendaal/Field 1993: xix). The representation of prison conditions by the journalist-narrator in "Ten Days in Roeland Street Jail", which focuses on the same elements as in "Out of Darkness", displays figurative language and is rich in similes: "[b]ehind its walls exists a world ruled by stony-eyed guards who have become as cold as the iron bars over the windows, and long-term convicts as calloused and 
hard as the stones which enclose them" (La Guma 1993b: 14). The "anecdotal" quality (Pointer 2001: xxxvi) of La Guma's journalistic writing is also notable in pieces like "The Machine" (1956) and "Wilton Zimasile Mkwayi: A Son of the People" (1957b). ${ }^{25}$ If at the level of content some of La Guma's short stories have originated from his articles, at a formal level it is rather his journalistic writing that acquires fictional traits.

After the very prolific decade of the Fifties, many writers were forced into exile and thus silenced, following the implementation of state censorship (see McDonald 2009: 32-72). A new generation of intellectuals began to emerge in the late Seventies with the advent of the Black Consciousness Movement, which deeply influenced artists and led to a new centrality of the representation of communities and their freedom struggle in works of art (Gaylard 2008: 199). ${ }^{26}$ A direct consequence of Black Consciousness was the foundation of Staffrider in 1978, a racially-inclusive magazine that became the forum for journalism, literary criticism, book reviews, creative writing - poetry, drama, short stories - and arts following a communitybased editorial line (McDonald 2009: 144). The first issue of March 1978, for example, includes journalistic columns and interviews, an excerpt from a play, sketches from a creative youth association, photographs, and, notably, short stories. The legacy of Drum in promoting shortstory writing was thus inherited by Staffrider (Trump 1988: 37).

Together with Staffrider, anthologies were published to archive black writing, most notably Mothobi Mutloatse's Forced Landing (1980) and Reconstruction (1981). These anthologies collect different genres and discourses, including both journalism and short stories among other texts, similarly to the anthologies of Can Themba, Alex La Guma, and Couzens' edition of R. R. R. Dhlomo's works. Moreover, many texts display features of generic indeterminacy which, for the first time in South African literary history, is supported by explicit theorisations. In the programmatic manifesto opening Forced Landing (1980), Mothobi Mutloatse introduces a new genre called "proemdra", a mixture of prose, poem, and drama: "We'll write our poems in a narrative form; we'll write journalistic pieces in poetry form; we'll dramatize our poetic experiences; we'll poeticise our historical drama" (1980: 5). Mutloatse outlines a precise "black aesthetics" in which the domains of politics and literature are inseparable, thus rejecting the conventional Western separation between different discourses and genres (Zander 1999: 194).

In 1984, Miriam Tlali (1933-2017), regular contributor to Staffrider, published a volume titled Mihloti. Echoing Mutloatse's anthologies and the eclectic structure of Staffrider itself, the book is divided into four sections: interviews, one short story, travelogues and, remarkably, New Journalism. ${ }^{27}$ The latter consists of one testimony titled "Detour into Detention", which narrates how the police arrested Miriam Tlali and other 92 people to prevent them from attending the funeral of Black Consciousness leader Steve Biko in 1977. Yet, the very same text had appeared six years before in the first issue of Staffrider as a short story under the title "Soweto Hijack! A story of our times" (Tlali 1978: 12). While it can be assumed that the Staffrider editorial committee wanted to avoid censorship (unsuccessfully) by labelling Tlali's piece as a fictional story on coeval events (Zander 1999: 265), "Soweto Hijack"/ "Detour into Detention" still possesses a marked literary flavour (see Androne 2013: 28). Tlali, author and 
Cadernos de Literatura Comparada

Journalism and the Black Short Story in English in Twentieth-Century South Africa

first-person narrator - she is referred to in the text as "Miriam" (Tlali 1978: 18) - recounts a real event with precise indications of time and place. ${ }^{28}$ However, the narrative structure of the piece is far from straightforward: the narrator starts her account reporting a conversation she had with her neighbour after her release; one of her neighbour's questions prompts the narrator's tale of the event. Tlali thus adopts the fictional device of the story in the story. The author-narrator's personal reflections alternate with precise descriptions and tight dialogue, but also with lyrical passages such as follows:

We were awakened by the haunting music of freedom songs. The 'captive' children had arisen from the hard concrete gaol floor undaunted, defiant and as resilient as ever. Their songs of hope, assurance and determination resounded through the sombre prison surroundings. They nursed their wounds and sang of the heroes of Africa. (idem: 15)

"Soweto Hijack"/"Detour into Detention" thus represents yet another instance of South African literary journalism in which the documentary impulse is counterbalanced by the use of literary techniques, making the terms "article" and "short story" become synonyms.

The boundary between conventional genres, and between fictional and factual discourse, has long been far less prominent in black South African writing than in Western literatures (Zander 1999: 45). ${ }^{29}$ In particular, the interdependence of journalism and short-story writing in English represents a fil rouge in the history of South African literature, as a diachronic approach can show. R. R. R. Dhlomo, Can Themba, Alex La Guma, and Miriam Tlali are representatives of different periods of South Africa's political and literary history - spanning over fifty years, from the pre-Apartheid era to its last decade. The fictional output of the discussed writers is as prolific and significant as their journalistic one, to the point that the two can often be considered one and the same, as in Tlali's "Soweto Hijack!" "Detour into Detention".

The genre contamination of journalism by the short story (and vice-versa) has been particularly prominent in South Africa due to the material conditions of publishing available to African writers, to the form of the short-story genre itself, to the role of the press, and, ultimately, to South Africa's socio-political history. If on the one hand these factors have produced several interesting instances of literary journalism, on the other hand the marked documentary traits of many fictional short stories have tended to overshadow their formal qualities and their status as "literature". As a result, "[t]he contingency of literariness itself" is constantly contested in these texts, while their political quality "triumphs almost inevitably", as Andrew van der Vlies notes for the literary work of Alex La Guma (2007: 127). A close reading of selected short stories and/or articles, however, may call for a revaluation of this "South African New Journalism" as a creative experimentation that challenges conventional generic categorisations, rather than as a mere literature "in extremis" (Attwell 2005: 13):

Finally, this productive clustering of fiction, life-writing, microhistory and journalism suggests how accounting for the literary in contemporary South Africa asks for a method of cross- 
reading. This would be one which plays across different genres and modes of address rather than remaining trapped within those protocols of symbolic exchange that thrive on an endless series of tired oppositions: "the novel" versus "history"; "aesthetics" versus "raw experience"; "committed" versus "formalist." If the task of the critic is to enlarge the space in which any given text can resonate, then much contemporary writing requires that traditional "literary" forms like the novel are read alongside or in counterpoint to all kinds of other work in prose [...]. (Twidle 2012: 24-25)

Twidle's suggestion that we should discard binary interpretative formulas must be also applied to the hybrid texts of the pre-Apartheid and Apartheid era, when the short-story form and journalism have influenced one another for a long time, producing interesting results from the intertwined points of view of ethics and aesthetics.

\section{NOTES}

\footnotetext{
* Marta Fossati is PhD candidate at the Department of Modern Languages at the University of Milan, Italy, and she recently completed a research period at Queen Mary University of London as visiting scholar. Her doctoral project focuses on the genre of the Anglophone short story in South Africa from a diachronic perspective.
}

${ }^{1}$ The term "New Journalism" originates from the title of an anthology of journalism edited by Tom Wolfe and E. W. Johnson in 1973.

${ }^{2}$ See also Worthington (2018: 102): "while the novel was dead or dying, the New Journalism was raising from its ashes, ready to claim the readership and the cultural cachet heretofore reserved for literary fiction".

${ }^{3}$ Apartheid was institutionalised in 1948 with the victory of the National Party in the country's elections, and it ended in 1994 with the democratic election of Nelson Mandela, member of the African National Congress, as South Africa's President.

${ }_{4}^{4}$ For instance, the Sunday Times has established a literary prize for non-fiction, the Alan Paton Award, in 1989 to recognise the non-fiction output of South African writers. See also Twidle (2012: 27).

${ }^{5}$ Country of My Skull (1998) is a non-fictional account of the hearings of the South African Truth and Reconciliation Commission (1996-2003), established to deal with the abuses perpetrated during Apartheid. As such, it mixes various genres and discourses: journalism, eye-witness accounts, personal reflections, and poetry.

${ }^{6}$ In this regard, see Horst Zander's seminal monograph titled Fact - Fiction - "Faction": A Study of Black South African Literature in English (1999).

${ }^{7}$ See Twidle (2012: 8): "For whereas during apartheid, it was the domain of literary fiction, specifically the short story and the novel, which provided the most acclaimed versions [...] of this southern Africa society, in the decades post-apartheid [...] the most significant literary production is judged to have shifted decisively into the realms of non-fiction". 
${ }^{8}$ Creative works submitted to mission presses, however, were often subject to censorship. An exemplary case is represented by the publication history of the novel Mhudi (1930) by Sol T. Plaatje.

${ }^{9}$ R. R. R. Dhlomo became assistant editor to The Bantu World in the Thirties and editor of the Zulu newspaper Ilanga Lase Natal from 1943. For details on Dhlomo's biography, see Skikna 1984.

${ }^{10}$ The term "induna" means "overseer". In the hierarchy of mine compounds, indunas were usually black men with some sort of privilege overseeing common black labourers and answering directly to the white chief.

${ }^{11}$ See the word "orgy" to describe the slaughter and the expression "to smack one's lips" (1975c: 27; 1975b: 67).

${ }^{12}$ Even though Couzens classifies it as an "article", the piece originally bore no label indicating its status as article or story on its publication in the Sjambok (Zander 1999: 248).

${ }_{13}$ When skimming the pages of the issues of The Bantu World of the year 1932, it can be noted that R. R. R. Dhlomo's hybrid pieces did not constitute an exception, but were rather the norm. The subtitle of a piece published on $19^{\text {th }}$ November 1932 by a certain S. M. Stanley-Silwana, for instance, recites "Facts in Fiction", thus confirming a widespread trend in early black South African short prose published in newspapers (see also Zander 1999: 360-363). As we have seen, it was also the structure of The Bantu World itself that encouraged the intermingling of articles and short stories.

${ }^{14}$ Couzens rightfully remarks that Dhlomo's mine stories are "unique" for the time, for they are the only "imaginative data" on the situation in mine compounds from the "black side" (Couzens 1975a: 2).

${ }^{15}$ Skikna interestingly links Dhlomo's journalistic activity with his background in a traditional Zulu society: both allowed the author to educate and guide his readers towards his views, and both enhanced the alleged factuality of Dhlomo's fictional stories. Dhlomo-the-journalist thus adopts the role of the oral poet in a traditional Zulu society, whose authority allows him to present his opinions as fact, and not as fiction (Skikna 1984: 164).

${ }^{16}$ For a discussion on the cross-fertilization between journalism and the short-story genre in the work by Herbert Dhlomo, see Iannaccaro 2019 and Fossati (forthcoming).

${ }^{17}$ The devices listed by Cowling remarkably echo the literary techniques used by New Journalists (see Hollowell 1977: 25-31). See Visser's interesting comparison: “Anyone familiar with American 'New Journalism' will recognize that Drum writers were working in the mode at least as long as their American counterparts who gave it its name".

${ }^{18}$ For a detailed discussion of South Africa's little magazines, see Gardiner 2004.

${ }^{19}$ The predominance of homodiegetic narrators and the drift towards documentary writing in black South African short stories of the Forties and Fifties also highlight an interesting connection between the short-story form and autobiography, another very prolific genre of South African black writing in English. Several of the Drum authors wrote autobiographies, and Themba's more mature short stories, such as "The Will to Die", can actually be categorised as life-writing. See Visser (1976: 50-54). ${ }^{20}$ Some expressions in "The Dube Train", such as "congested trains, filled with sour-smelling humanity" (Themba 1985: 33) remind of "Terror in the Trains": "congestion on the trains [...] jam-packed with gasping frightened humanity" (Themba 1985: 112).

${ }^{21}$ Edgar Allan Poe first theorised his notion of the unity of effect while reviewing Nathaniel Hawthorne's Twice-Told Tales in 1842.

${ }^{22}$ Textual evidence of this generic proximity is the confusion in categorising some short pieces by La Guma, as in Themba's case. For instance, Cecil Abrahams, at the end of his biography on La Guma, lists "A Christmas Story", "Come Back to Tashkent", and "Exile" as "articles" and not "short stories" (Abrahams 1985: 148-149).

${ }^{23}$ Drum journalist Henry Nxumalo is the author and protagonist of the exposé of prison conditions in South Africa, the narrative reportage "Mr Drum Goes to Jail" - he let himself be arrested to document prison conditions first-hand. Similarly 
to La Guma, Nxumalo criticises the "bestial" treatment of prisoners by both the guards and long-term prisoners (Nxumalo 2001: 46).

${ }_{24}$ The articles are "The Dead-End Kids of Hanover Street", "Ten Days in Roeland Street Jail", and "Law of the Jungle", all published in New Age on $20^{\text {th }}$ September, $27^{\text {th }}$ September, and $4^{\text {th }}$ October 1956 respectively. They have been reprinted in Liberation Chabalala. The World of Alex La Guma, where these articles are placed just before "Out of Darkness" on purpose.

25 "The Machine" is an article denouncing the behaviour of a government official, published in Fighting Talk in 1956. Bernth Lindfors (1966: 58-59) classifies the piece as a short story - and "The Machine" is in fact published on the same page of the periodical as Alfred Hutchinson's short story "No Pass...". As often happens with the articles written by La Guma, his narrative style is "suggestive of literary design" (Cornwell 1979: 43), and therefore the piece's status is difficult to categorise. See Cornwell (1979: 91-99) and Zander (1999: 440-444).

${ }^{26}$ Black Consciousness was a philosophical, cultural, and political movement started by university students and led by Steve Biko. It rejected the sense of inferiority instilled in black South Africans - including Indians and coloured people - by centuries of colonial oppression, calling instead for a revaluation of a shared and communal "black identity" (see Gaylard 2008: 196203).

${ }^{27}$ As we have seen, the textual practice of mixing factual and fictional discourse can be identified in South Africa starting from the late Twenties. Yet, the first sustained theorisations on it and the explicit link with American New Journalism - Tom Wolfe's anthology dates back to 1973 - are to be found only in the late Seventies.

${ }^{28}$ Worthington uses the term "autofiction" when discussing the correspondence between author/journalist and narrator in New Journalism (2018: 98).

${ }^{29}$ Another interesting instance of literary journalism worth exploring in South Africa's cultural panorama is represented by the journalistic genre of the column. All the writers discussed in the present essay authored regular columns: Dhlomo's " $\mathrm{R}$. Roamer Esq." in The Bantu World, Themba's "Talk o' the Rand" in Drum, La Guma's "Up My Alley" in New Age, and Tlali's "Soweto Speaking" in Staffrider. See Zander (1999: 265-279); Sandwith (2018); Odendaal/Field (1993).

\section{Works Cited}

Abrahams, Cecil (1985), Alex La Guma, Boston, Twayne Publishers.

Androne, Mary Jane (2013), "Writing Apartheid: Miriam Tlali's Soweto Stories", in Jane Bryce et alii (eds.), Writing Africa in the Short Story: African Literature Today, Woodbridge, James Currey, 25-39, <www.jstor.org/stable/10.7722/j.ctt3fgmkz.7> (last accessed 13/01/2021).

Attwell, David (2005), Rewriting Modernity: Studies in Black South African Literary History, Scottsville, University of KwaZulu-Natal Press.

Bethlehem, Louise (2001), "'A Primary Need as Strong as Hunger': The Rhetoric of Urgency in South African Literary Culture Under Apartheid", Poetics Today, vol. 22, n² 2, 365-389, <https://muse.jhu.edu/article/27855> (last accessed 04/01/2021). 
Cadernos de Literatura Comparada

Journalism and the Black Short Story in English in Twentieth-Century South Africa

Choonoo, R. Neville (1997), "The Sophiatown Generation: Black Literary Journalism during the 1950s", in Les Switzer (ed.), South Africa's Alternative Press: Voices of Protest and Resistance, 1880-1960, Cambridge, Cambridge University Press, 252-265.

Cornwell, Gareth (1979), "Protest in Fiction: An Approach to Alex La Guma", Dissertation, Rhodes University, <https://core.ac.uk/download/pdf/145041112.pdf> (last accessed $11 / 12 / 2020)$.

Couzens, Tim (1974), "Black Literature in South Africa 1900-1950", African Studies Institute Seminar Papers, University of the Witwatersrand, <http://hdl.handle.net/10539/8605> (last accessed 04/01/2021).

-- (1975a), "Introduction", English in Africa, vol. 2, n 1, 1-7, <https://www.jstor.org/stable/ i40009019> (last accessed 18/12/2020).

-- (1975b), "Appendix", English in Africa, Vol. 2, n 1, 58, <https://www.jstor.org/stable/ i40009019> (last accessed 18/12/2020).

- - (1976), "A short history of The World (and other Black South African newspapers)", African Studies Institute Seminar Papers, University of the Witwatersrand, <http://wiredspace. wits.ac.za/bitstream/handle/10539/8608/ISS-105.pdf?sequence=1\&isAllo wed=y > (last accessed 04/01/2021).

Cowling, Lesley (2016), "Echoes of an African Drum: The Lost Literary Journalism of 1950 s South Africa", Literary Journalism Studies, vol. 8, n 1, 9-32, <https://www.researchgate. net/publication/303825147_Echoes_of_an_African_Drum_The_lost_literary_ journalism_of_1950s_South_Africa> (last accessed 01/12/2020).

Dhlomo, H. I. E. (1975), "Three Famous African Authors I Knew: R. R. R. Dhlomo" [1946], English in Africa, vol. 2, $\mathrm{n}^{\circ}$ 1, 8-12, <https://www.jstor.org/stable/40238305> (last accessed 13/01/2021).

Dhlomo, R. R. R. (1975a), "The Compound Induna and Compound Interest" [1930], English in Africa, vol. 2, $\mathrm{n}^{\circ}$ 1, 63-65, <https://www.jstor.org/stable/i40009019> (last accessed 18/12/2020).

-- (1975b), "Wholesale Dog Murder" [1930], English in Africa, vol. 2, n 1, 66-67, <https:// www.jstor.org/stable/i40009019> (last accessed 18/12/2020).

-- (1975c), "The Dog Killers" [1930], English in Africa, vol. 2, n 1, 26-28, <https://www.jstor. org/stable/i40009019> (last accessed 18/12/2020).

-- (1975d), "Ukugweba" [1932], English in Africa, vol. 2, n 1, 39-42, <https://www.jstor.org/ stable/i40009019> (last accessed 18/12/2020).

Ehmeir, Walter (1995), "Publishing South African Literature in English in the 1960s", Research in African Literatures, vol. 26, $\mathrm{n}^{\circ}$ 1, 111-131, <https://www.jstor.org/stable/3820092> (last accessed 12/01/2021).

Field, Roger (2010), Alex La Guma: A Literal and Political Biography, Woodbridge, Boydell and Brewer Ltd.

Fossati, Marta, "Literariness and Genre Mobility: Journalistic Features in the Short Stories by Herbert Dhlomo", forthcoming. 
Gardiner, Michael (2004), South African Literary Magazines 1956-1978, Johannesburg, Ex Libris Press.

Gaylard, Rob (2008), "Writing Black: The South African Short Story by Black Writers", Dissertation, University of Stellenbosch, <http://scholar.sun.ac.za/handle/10019.1/1202> (last accessed 20/01/2021).

Iannaccaro, Giuliana (2019), "'The great change': Herbert Dhlomo's 'An Experiment in Colour' ', Annali di Ca' Foscari. Serie occidentale, vol. 53, 395-408, <http://doi.org/10.30687/ AnnOc/2499-1562/2019/01/030> (last accessed 24/01/2021).

Iftekharrudin, Farhat (2003), "Fictional Nonfiction and Nonfictional Fiction", in Farhat Iftekharrudin et alii (eds.), The Postmodern Short Story: Forms and Issues, Westport, Greenwood Publishing Group, 23-24.

Hollowell, John (1977), Fact and Fiction: The New Journalism and the Nonfiction Novel, Chapel Hill, The University of North Carolina Press.

Krog, Antjie (1999), Country of My Skull, London, Jonathan Cape [1998].

La Guma, Alex (1956), “The Machine”, Fighting Talk, vol. 12, n 10, 8, <https://disa.ukzn. ac.za/sites/default/files/pdf_files/FiOct56.pdf> (last accessed 11/12/2020).

-- (1957a), "Out of the Darkness", Africa South, vol. 2, n 1, 118-122, <https://disa.ukzn.ac.za/ sites/default/files/pdf_files/asoct57.pdf> (last accessed 21/12/2020).

-- (1957b), "Treason Trial Profile. Wilton Zimasile Mkwayi: A Son of the People", Fighting Talk, vol. 11, $n^{\circ}$ 3, 4, <https://disa.ukzn.ac.za/sites/default/files/pdf_files/FiMar57.pdf> (last accessed 16/12/2020).

-- (1993), "Ten Days in Roeland Street Jail" [1956], in André Odendaal / Roger Field (eds.), Liberation Chabalala: The World of Alex La Guma, Bellville, Mayibuye Books, 14-16.

Lindfors, Bernth (1966), "Post-War Literature in English by African Writers from South Africa: A Study of the Effects of Environment Upon Literature", Phylon, vol. 27, n 1, 5062, <http://www.jstor.org/stable/273321> (last accessed 18/12/2020).

Mbi, Fezile (1956), "The Family Boy", New Age, vol. 2 n 51, <https://disa.ukzn.ac.za/sites/ default/files/pdf_files/nav2n5156.pdf> (last accessed 30/11/2020).

McDonald, Peter (2009), The Literature Police: Apartheid Censorship and Its Cultural Consequences, New York, Oxford University Press.

Morano, Michele (2003), "Facts and Fancy: The 'Nonfiction Short Story'", in Farhat Iftekharrudin et alii (eds.), The Postmodern Short Story: Forms and Issues, Westport, Greenwood Publishing Group, 35-46.

Mutloatse, Mothobi (ed.) (1980), "Introduction", in Forced Landing. Africa South: Contemporary Writings, Johannesburg, Ravan Press, 1-7.

Nxumalo, Henry (2001), "Mr Drum Goes to Jail" [1954], in Michael Chapman (ed.), The Drum Decade: Stories from the 1950s, Johannesburg, Ravan Press, 135-144.

Odendaal, Andre / Roger Field (eds.) (1993), "Introduction", in Liberation Chabalala: The World of Alex La Guma, Mayibuye Books, Bellville, ii-xxvi.

Orlofsky, Michael (2003), "Historiografiction: The Fictionalization of History in the Short 
Cadernos de Literatura Comparada

Journalism and the Black Short Story in English in Twentieth-Century South Africa

Story", in Farhat Iftekharrudin et alii (eds.), The Postmodern Short Story: Forms and Issues, Westport, Greenwood Publishing Group, 47-62.

Peterson, Bhekizizwe (2006), "The Bantu World and the World of the Book: Reading, Writing, and 'Enlightenment'”, in Karin Barber (ed.), Africa's Hidden Histories: Everyday Literacy and Making the Self, Bloomington, Indiana University Press, 236-257.

Pointer, Fritz (2001), A Passion to Liberate: La Guma's South Africa - "Images of District Six", Trenton, Africa World Press.

Pratt, Marie Louise (1994), "The Short Story: The Long and The Short of It", in Charles May (ed.), The New Short Story Theories, Athens, Ohio University Press, 91-113.

Sachs, Albie (1998), "Preparing Ourselves for Freedom" [1989], in Derek Attridge / Rosemary Jolly (eds.), Writing South Africa: Literature, Apartheid, and Democracy, 1970-1995, Cambridge, Cambridge University Press, 239-248.

Sandwith, Corinne (2018), "Reading and Roaming the Racial City: R. R. R. Dhlomo and The Bantu World", English in Africa, vol. 45, n 3, 17-39, <https://dx.doi.org/10.4314/eia. v45i3.2> (last accessed 16/01/2021).

Shaw, Valerie (1983), The Short Story: A Critical Introduction, London, Longman.

Skikna, Shelley (1984), "Son of the Sun and Son of the World: the Life and Works of R. R. R. Dhlomo", Dissertation, University of the Witwatersrand, <http://wiredspace.wits.ac.za/ handle/10539/24669> (last accessed 13/01/2021).

Stanley-Silwana, S. M. (1932), "Mteto Becomes a Criminal: Facts in Fiction", The Bantu World, 19/11/1932, 3.

Themba, Can (1982), The Will to Die, Cape Town, Africasouth Paperbacks [1972].

-- (1985), The World of Can Themba, Braamfontein, Ravan Press.

Tlali, Miriam (1978), "Soweto Hijack!", Staffrider, vol. 1, n 1, 12-20, <https://www.sahistory. org.za/archive/staffrider-vol-i-no-i-march-1978> (last accessed 12/01/2021).

-- (1984), Mihloti, Johannesburg, Skotaville.

Twidle, Hedley (2012), “'In a Country Where You Couldn't Make this Shit up?': Literary NonFiction in South Africa", Safundi, vol. 13, n 1-2, 5-28, <https://doi.org/10.1080/17533171. 2011.642586> (last accessed 17/11/2020).

Trump, Martin (1988), "Black South African Short Fiction in English since 1976", Research in African Literatures, vol. 19, $\mathrm{n}^{\circ}$ 1, 34-64, <http://www.jstor.org/stable/3819582> (last accessed 15/01/2021).

Van der Vlies, Andrew (2007), South African Textual Cultures: White, Black, Read All Over, Manchester, Manchester University Press.

Visser, Nick(1976), "South Africa: The Renaissance That Failed", The Journal of Commonwealth Literature, vol. 11, n 1, 42-57, <https://doi.org/10.1177\%2F002198947601100102> (last accessed 08/01/2021).

Wicomb, Zoë (2001), "South African Short Fiction and Orality", in Jacqueline Bardolph (ed.), Telling Stories: Postcolonial Short Fiction in English, Amsterdam, Rodopi, 157-170.

Wolfe, Tom / E. W. Johnson (eds.) (1996), The New Journalism, London, Picador [1973]. 
Worthington, Marjorie (2018), "The New Journalism as the New Fiction: Tom Wolfe, Norman Mailer, Hunter S. Thompson, Joan Didion, Mark Leyner, and Bret Easton Ellis", in The Story of "Me": Contemporary American Autofiction, Lincoln, University of Nebraska Press, 92-124, <https://doi.org/10.2307/j.ctv7fmfvx.7> (last accessed 14/01/2021).

Zander, Horst (1999), Fact - Fiction - "Faction": A Study of Black South African Literature in English, Tübingen, Gunter Narr. 